\title{
Comparison of floating chamber and eddy covariance measurements of lake greenhouse gas fluxes
}

\author{
E. Podgrajsek ${ }^{1}$, E. Sahlée ${ }^{1}$, D. Bastviken ${ }^{2}$, J. Holst ${ }^{3}$, A. Lindroth ${ }^{3}$, L. Tranvik ${ }^{4}$, and A. Rutgersson ${ }^{1}$ \\ ${ }^{1}$ Uppsala University, Dept. of Earth Sciences, Air, Water and Landscape Sciences, Uppsala, Sweden \\ ${ }^{2}$ Linköping University, Dept. of Thematic Studies - Water and Environmental Studies, Linköping, Sweden \\ ${ }^{3}$ Lund University, Dept. of Physical Geography and Ecosystem Science, Lund, Sweden \\ ${ }^{4}$ Uppsala University, Dept. of Ecology and Genetics, Limnology, Uppsala, Sweden \\ Correspondence to: E. Podgrajsek (eva.podgrajsek@geo.uu.se)
}

Received: 6 November 2013 - Published in Biogeosciences Discuss.: 25 November 2013

Revised: 27 June 2014 - Accepted: 30 June 2014 - Published: 12 August 2014

\begin{abstract}
Fluxes of carbon dioxide $\left(\mathrm{CO}_{2}\right)$ and methane $\left(\mathrm{CH}_{4}\right)$ from lakes may have a large impact on the magnitude of the terrestrial carbon sink. Traditionally lake fluxes have been measured using the floating chamber (FC) technique; however, several recent studies use the eddy covariance (EC) method. We present simultaneous flux measurements using both methods at lake Tämnaren in Sweden during field campaigns in 2011 and 2012. Only very few similar studies exist. For $\mathrm{CO}_{2}$ flux, the two methods agree relatively well during some periods, but deviate substantially at other times. The large discrepancies might be caused by heterogeneity of partial pressure of $\mathrm{CO}_{2}\left(p \mathrm{CO}_{2 w}\right)$ in the $\mathrm{EC}$ flux footprint. The methods agree better for $\mathrm{CH}_{4}$ fluxes. It is, however, clear that short-term discontinuous FC measurements are likely to miss important high flux events.
\end{abstract}

\section{Introduction}

Atmospheric concentrations of greenhouse gases, such as methane $\left(\mathrm{CH}_{4}\right)$ and carbon dioxide $\left(\mathrm{CO}_{2}\right)$, have increased significantly since pre-industrial times (Forster et al., 2007). Knowledge of both natural and anthropogenic sources and sinks of these greenhouse gases is needed for a better understanding of the global carbon cycle. During the last decade several studies have shown that lakes, even though they cover $<3 \%$ of the land surface (Downing et al., 2006), can significantly change the magnitude of the terrestrial carbon sink, through exchange processes involving both $\mathrm{CO}_{2}$ (e.g. Cole et al., 2007) and $\mathrm{CH}_{4}$ (e.g. Bastviken et al., 2011). Hence, it is important to further study lake processes involving $\mathrm{CO}_{2}$ and $\mathrm{CH}_{4}$ flux.

The diffusive flux of a gas is controlled by the difference in concentration of the gas in the water and air and the efficiency of the gas transfer:

$F_{\text {gas }}=k \times\left(C_{\text {gas, w }}-C_{\text {gas,eq }}\right)$,

where $F_{\text {gas }}$ is the gas flux $\left(\mathrm{mol} \mathrm{m}^{-2} \mathrm{~s}^{-1}\right), k$ is the transfer velocity $\left(\mathrm{m} \mathrm{s}^{-1}\right)$ and $C_{\text {gas, }}\left(\mathrm{mol} \mathrm{m}^{-3}\right)$ is the gas concentrations in the water. $C_{\mathrm{gas}, \text { eq }}\left(\mathrm{mol} \mathrm{m}^{-3}\right)$ is the gas concentration in equilibrium with the partial pressure of the gas in the air above the water surface as calculated with Henry's law (Cole and Caraco, 1998). The transfer velocity is normally parameterized using the $10 \mathrm{~m}$ wind speed only (e.g. Cole and Caraco, 1998; Wanninkhof, 1992). However, many studies have stressed that other processes such as microwave breaking (Zappa et al., 2001), bubbles (e.g. Woolf, 1993) and water-side convection (e.g. Eugster et al., 2003; MacIntyre et al., 2001; Rutgersson and Smedman, 2010; Rutgersson et al., 2011) also affect the transfer velocity.

Instead of calculating the gas flux with Eq. (1), direct measurements of gas accumulation in floating chambers (the FC method) and the eddy covariance (EC) method can be used. The FC method is an inexpensive and simple method frequently used to measure gas fluxes from lakes (e.g. Bastviken et al., 2011; Huttunen et al., 2003; Riera et al., 1999). It can, however, be questioned how well FC measurements represent the flux from the entire lake, since the chambers only cover a very small area, typically a few tenths of a square metre. If the chambers are sampled manually the 
method is labour intense. For $\mathrm{CO}_{2}$, which typically equilibrates rapidly with chamber headspace, short deployment periods (e.g. 20-40 min) are necessary. For $\mathrm{CH}_{4}$ longer measurements (e.g. 24h) are possible (Bastviken et al., 2010). When both $\mathrm{CO}_{2}$ and $\mathrm{CH}_{4}$ are studied, short-term chamber deployments are common typically only during daytime, giving discontinuous measurements.

The EC method requires high frequency sampling using instrumentation with high resolution. The EC flux represents the flux originating from an upwind area called the footprint, typically several hundred square metres, varying in size depending on e.g. the height of the instruments above the surface, the atmospheric stability, surface roughness and wind speed. The EC method has frequently been used to measure gas fluxes from terrestrial sites and oceans (e.g. Baldocchi, 2003; Rutgersson et al., 2011; Sahlée et al., 2007). During recent years EC measurements have been made also over lakes, mainly for $\mathrm{CO}_{2}$ flux (e.g. Eugster et al., 2003; Huotari et al., 2011; Jonsson et al., 2008; Vesala et al., 2006) but in a few cases also for $\mathrm{CH}_{4}$ flux (Eugster et al., 2011; Podgrajsek et al., 2014; Sahlée et al., 2014; Schubert et al., 2012). The EC method yields continuous measurements with limited labour, but requires expensive instrumentations and extensive data post-processing.

Importantly, fluxes measured with the EC and FC methods represent different surface source areas. If fluxes are horizontally heterogeneous in an EC footprint area where the chambers are located, it is likely that the fluxes measured with the two methods will disagree.

The flux chambers and EC methods have been compared in several studies of terrestrial sites (e.g. Wang et al., 2010) and wetlands (e.g. Godwin et al., 2013). Chambers and the EC methods are in relatively good agreement in these studies, and the discrepancy still observed is mainly due to spatial heterogeneity of the gas flux. Comparisons over water bodies are sparse (Eugster et al., 2011; Schubert et al., 2012), yet the results, only for $\mathrm{CH}_{4}$ flux, show that the methods are of the same order of magnitude. Since both methods are widely used, further parallel studies with more direct comparisons are needed.

In this study, we compare 51 and 18 simultaneous measurements with the $\mathrm{FC}$ and $\mathrm{EC}$ methods of $\mathrm{CH}_{4}$ and $\mathrm{CO}_{2}$ fluxes, respectively. Additionally, spatial variability of $\mathrm{CH}_{4}$ flux using the FC method is studied.

\section{Methods}

\subsection{Site}

The flux measurements were made at lake Tämnaren in central Sweden $\left(60^{\circ} 09^{\prime} \mathrm{N}, 17^{\circ} 20^{\prime} \mathrm{E}\right)$. The lake is shallow with a mean depth of $1.3 \mathrm{~m}$ (maximum depth of $2 \mathrm{~m}$ ) and covers an area of $38 \mathrm{~km}^{2}$. Mixed forest surrounds the lake except to the

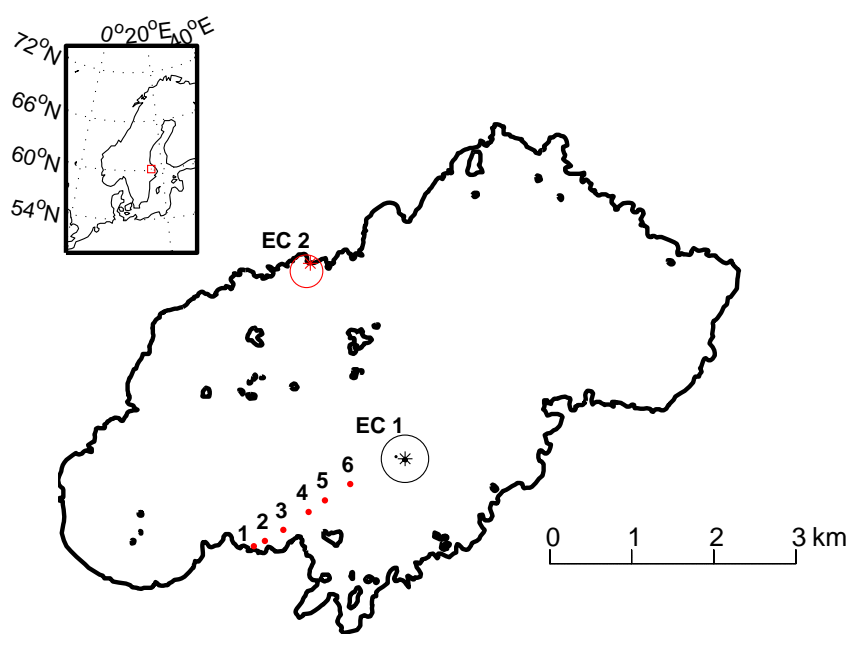

Figure 1. Map of Lake Tämnaren. Upper left inset map marks the position of the lake (red box). The two EC towers denoted with EC1, positioned on the Rättarharet Island and EC2, positioned on the northwest shore (marked with black and red stars). The black and red circles around EC1 and EC2 represent approximate positions of FCs placed in the footprint of the towers. The red dots, numbered 1-6, represent the positions of the chambers used in the transect.

north where there are agriculture fields and the lake has an extensive cover of submersed macrophytes.

\subsection{Instrumentation and data collection}

From September 2010 to September 2012 an EC tower was situated on the small island called Rättarharet in the centre of the lake, approximately $1 \mathrm{~km}$ from the nearest land, to the south east (Fig. 1). The tower (EC1) was equipped with the following EC instrumentation $4.7 \mathrm{~m}$ above the lake surface: sonic anemometer (WindMonitor, Gill Instruments, Lymington, UK) for measurements of the 3-D wind components and virtual (sonic) temperature, LI-7700 open gas analyser for $\mathrm{CH}_{4}$ measurements (LI-COR Inc., Lincoln, NE, USA) and LI-7500A open path gas analyser for $\mathrm{CO}_{2}$ and water vapour measurements (LI-COR Inc., Lincoln, NE, USA). Additional instrumentation in the tower is described in Podgrajsek et al. (2014) and Sahlée et al. (2014). Between 7 June 2011 and 9 June 2011 a first intensive flux measuring field campaign was conducted. During the campaign the FCs were placed in the footprint of the tower (Fig. 1). A mean FC flux of 4-6 chambers was used to compare to the mean value of the simultaneous EC measurement. The FC deployment time ranged between $30 \mathrm{~min}$ and $5 \mathrm{~h}$ for $\mathrm{CH}_{4}$ flux measurements and was $30 \mathrm{~min}$ for the $\mathrm{CO}_{2}$ flux measurements. During fall, 1 September 2011 to 19 October 2011, FC measurements were made biweekly in the footprint of EC1.

A second field campaign was held between 12 June 2012 and 15 June 2012. During this campaign an additional EC tower (EC2) was mounted on the northwest shore of 
Tämnaren (Fig. 1). The second tower was equipped with a sonic anemometer for 3-D wind components (USA-1, METEK, Elmshorn, Germany) and virtual (sonic) temperature, a LI-7500 open-path gas analyser for $\mathrm{CO}_{2}$ and $\mathrm{H}_{2} \mathrm{O}$ measurements (LI-COR Inc., Lincoln, NE, USA) and a LI7700 open-path gas analyser for $\mathrm{CH}_{4}$ measurements (LICOR Inc., Lincoln, NE, USA). Five FCs were deployed in the footprint of EC2 (Fig. 1) in four deployments with deployment times ranging from 5 to $22 \mathrm{~h}$. Additionally, a float was situated approximately $70 \mathrm{~m}$ west of EC1 with a SAMI sensor (Submersible autonomous moored instrument, Sunburst Sensors, MT, USA) continuously measuring partial pressure of $\mathrm{CO}_{2}$ in the water $\left(p \mathrm{CO}_{2 \mathrm{w}}\right)$. During this campaign, additional $\mathrm{FC}$ measurements were made in a transect from the shore to EC1 (Fig. 1) to study spatial variations in $\mathrm{CH}_{4}$ flux. The deployment times for these $\mathrm{FC}$ measurements ranged from $30 \mathrm{~min}$ to $5.5 \mathrm{~h}$.

See Table 1 for a summary of the measurements made during the different periods.

\subsection{Chamber flux measurements}

Floating chambers were made of inverted plastic buckets (polymethylene/plexiglas) covered with reflective alumina tape, reaching approximately $3 \mathrm{~cm}$ into the water and equipped with Styrofoam floats. The chambers covered an area of $0.03 \mathrm{~m}^{2}$ and had a volume of $5 \mathrm{dm}^{3}$. For sampling, a port was fitted, made of polyurethane tubing connected with a three-way luer-lock valve (Becton Dickinson). This chamber type yields negligible flux bias compared to "open" methods such as $\mathrm{SF}_{6}$ tracer additions or water turbulence based measurements of gas exchange (Cole et al., 2010; Gålfalk et al., 2013). Air samples were taken using $60 \mathrm{~mL}$ plastic syringes (Becton Dickinson, Plastipak) equipped with threeway luer-lock valves from the chamber at the start and the end of the chamber deployment. During the field campaigns in 2011 and 2012, the air samples were analysed at the site within $24 \mathrm{~h}$, using an optical greenhouse gas analyser (DLT100, Los Gatos Research Inc.) equipped with the optional port for discrete sample injection, acquiring gas concentrations of $\mathrm{CH}_{4}$ and $\mathrm{CO}_{2}$. During the $\mathrm{FC}$ measurements in fall 2011 the samples were transferred to saltwater vials and stored up to a month prior to analysis on an Agilent 7890 gas chromatograph with a methanizer and a flame ionization detector (FID). The storage vials were prepared by filling them completely with saturated $\mathrm{NaCl}$ solution and capped with $10 \mathrm{~mm}$ thick massive butyl rubber stoppers (Apodan, Denmark). The solution was replaced with the gas sample by injecting the sample holding the vial upside down and allowing $\mathrm{NaCl}$ solution to escape through a second needle. This procedure was described in detail in Bastviken et al. (2010) and can be used to preserve $\mathrm{CH}_{4}$ samples during very long periods. However, our tests showed that an irregular proportion, and sometimes as much as $10 \%$ of the $\mathrm{CO}_{2}$, is lost during
Table 1. Summary of measurements during different periods.

\begin{tabular}{|c|c|}
\hline Period & Measurements \\
\hline Sep 2010 to & EC1, air temperature, wind speed, air pres- \\
\hline Sep 2012 & sure \\
\hline 7 Jun 2011 to & $\mathrm{EC} 1, \mathrm{FCs}$, headspace water $\mathrm{CO}_{2}$ and $\mathrm{CH}_{4}$ \\
\hline 9 Jun 2011 & $\begin{array}{l}\text { concentrations, water and air temperature, } \\
\text { wind speed, air pressure }\end{array}$ \\
\hline $\begin{array}{l}1 \text { Sep } 2011 \text { to } \\
19 \text { Oct } 2011\end{array}$ & $\begin{array}{l}\mathrm{EC} 1, \mathrm{FCs} \text {, air temperature, wind speed, air } \\
\text { pressure }\end{array}$ \\
\hline $\begin{array}{l}12 \text { Jun } 2012 \text { to } \\
15 \text { Jun } 2012\end{array}$ & $\begin{array}{l}\mathrm{EC} 1, \mathrm{FCs}, \mathrm{EC} 2 \text {, headspace water } \mathrm{CH}_{4} \text { con- } \\
\text { centration, continuous } p \mathrm{CO}_{2 \mathrm{w}} \text {, water and air } \\
\text { temperature, wind speed, air pressure }\end{array}$ \\
\hline
\end{tabular}

the sample transfer, precluding the use of the storage vials to estimate $\mathrm{CO}_{2}$ gas flux.

Using the difference of gas concentration between the initial and end sample, the FC flux of $\mathrm{CH}_{4}$ and $\mathrm{CO}_{2}$ can be calculated using a simple linear approximation:

$\mathrm{FX}_{\mathrm{FClinear}}=\frac{V}{R \times T \times A} \times \frac{\left(\mathrm{Gas}_{\mathrm{end}}-\mathrm{Gas}_{\text {int }}\right)}{\left(t_{\mathrm{end}}-t_{\text {int }}\right)}$

where $V$ is the volume of the chamber $\left(\mathrm{m}^{3}\right), R$ is the ideal gas constant $\left(\mathrm{m}^{3}\right.$ atm K $\left.{ }^{-1} \mathrm{~mol}^{-1}\right), T$ is the air temperature $(\mathrm{K}), A$ is the area that the chamber cover $\left(\mathrm{m}^{2}\right), \mathrm{Gas}_{\text {int }}$ and $\mathrm{Gas}_{\text {end }}$ are the gas partial pressures from the initial and end air samples (atm), respectively, and $t_{\text {int }}$ and $t_{\text {end }}$ are the start and end time of the measurement, respectively. However, as mentioned in the introduction, the flux of a gas over a water-air interface is driven by the concentration difference between the water and air and the transfer velocity, see Eq. (1). A flux calculated with a simple linear approximation (Eq. 2) will thus underestimate the true flux since the driving concentration difference will decrease during the sampling interval. This underestimation was compensated for by combining Eq. (1) and Eq. (2) and solving for the initial $k$ using a non-linear differential equation. This equation describes how flux into the chamber varies over time given how the concentration gradient develops (shown in detail in Bastviken et al., 2004). When the initial $k$ is known, Eq. (1) was used for calculating the flux. For these corrected flux calculations, also values of $\mathrm{CH}_{4}$ and $\mathrm{CO}_{2}$ concentrations in the water and ambient air are needed. For measurements of $\mathrm{CH}_{4}$ concentration in the water, $40 \mathrm{~mL}$ of surface water was sampled with a syringe and equilibrated with $20 \mathrm{~mL}$ air headspace in the same syringe and shaken for at least 1 minute. The concentration of $\mathrm{CH}_{4}$ in both the background air and the equilibrated syringe headspace was measured. With information about the headspace and water volumes, the temperature and Henry's law, the $\mathrm{CH}_{4}$ concentration in the water was calculated as described in Bastviken et al. (2010). During the first field campaign in 2011 the same procedure as for $\mathrm{CH}_{4}$ was used for obtaining $\mathrm{CO}_{2}$ water concentrations, but with larger headspace to water sample volumes because of ex- 


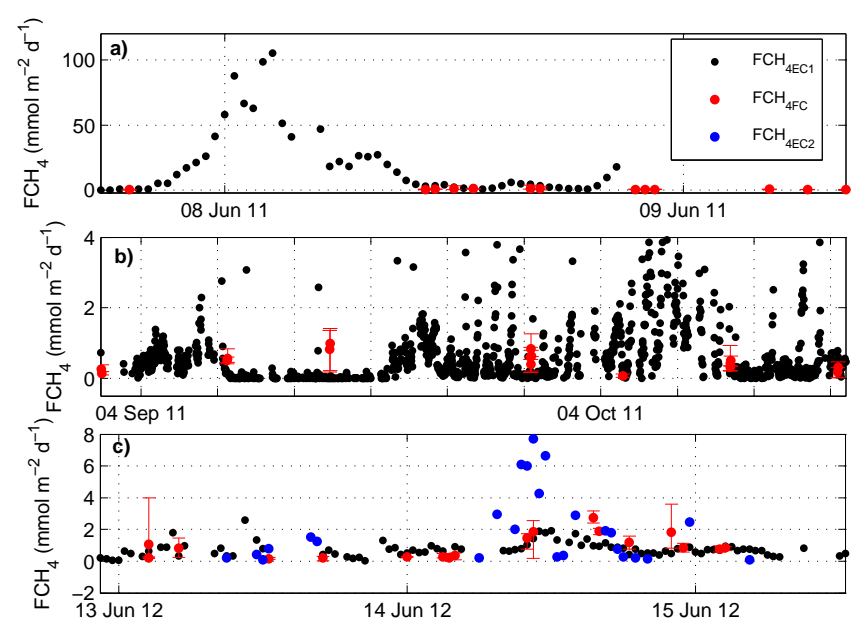

Figure 2. Time series of $\mathrm{FCH}_{4 \mathrm{EC} 1}$ black dots, $\mathrm{FCH}_{4 \mathrm{EC} 2}$ blue dots and $\mathrm{FCH}_{4 \mathrm{FC}}$ red dots (only FCs with 30 min deployment times positioned in $\mathrm{EC} 1$ footprint). The bars on $\mathrm{FCH}_{4 \mathrm{FC}}$ represent the maximum and minimum $\mathrm{FCH}_{4 \mathrm{FC}}$ from the individual chambers during one deployment.

pected near-equilibrium $\mathrm{CO}_{2}$ concentrations which require high sensitivity in measurements. Therefore a sample bottle with $1075 \mathrm{~mL}$ water and $50 \mathrm{~mL}$ air headspace was used. During the second field campaign in 2012 the SAMI sensor was operational on the float and thus headspace $\mathrm{CO}_{2}$ concentration measurements were not made.

\subsection{Eddy covariance method}

The following procedure for the EC flux measurements was used: double rotation of the sonic data, de-spiking and detrending over $30 \mathrm{~min}$ averaging periods, time lag calculations and corrections of the gas densities according to Webb et al. (1980) and McDermitt et al. (2010). For a more detailed description see Podgrajsek et al. (2014) and Sahlée et al. (2014). The EC data fulfilling the following criteria were used: wind direction from the lake, RSSI (received signal strength indicator, measure of the LI-7700 signal strength) $>30 \%$ when logged, wind speed $>1 \mathrm{~m} \mathrm{~s}^{-1}$, no precipitation and high quality power spectra.

\section{Results and discussion}

\subsection{Methane flux comparison}

Time series of $\mathrm{CH}_{4}$ flux $\left(\mathrm{FCH}_{4}\right)$ measured with the EC method, $\mathrm{FCH}_{4 \mathrm{EC}}$, and with the $\mathrm{FC}$ method, $\mathrm{FCH}_{4 \mathrm{FC}}$, are shown in Fig. 2. During 2011 (Fig. 2a), the magnitudes of $\mathrm{FCH}_{4 \mathrm{EC} 1} \quad\left(\right.$ mean $\left.=6.15 \mathrm{mmol} \mathrm{m}^{-2} \mathrm{~d}^{-1}\right)$ were substantially larger than in $2012\left(\right.$ mean $\left.=4.56 \mathrm{mmol} \mathrm{m}^{-2} \mathrm{~d}^{-1}\right)$. Note that only the $30 \mathrm{~min}$ chambers are shown in Fig. 2. Maximum values for the entire data set ranged up to $100 \mathrm{mmol} \mathrm{m}^{-2} \mathrm{~d}^{-1}$, which is in the same range as fluxes previously reported

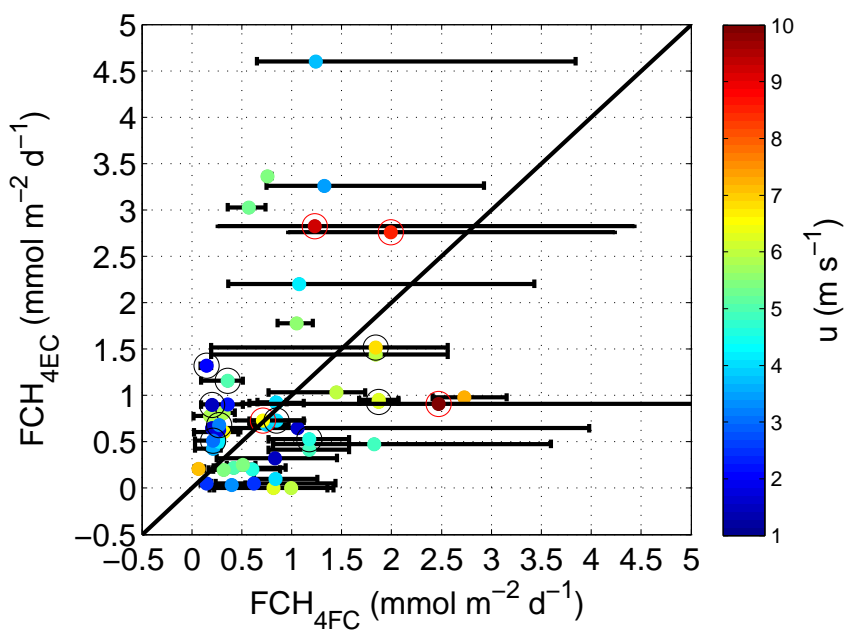

Figure 3. $\mathrm{FCH}_{4 \mathrm{FC}}$, i.e. mean values of 4-6 FCs deployed in the flux footprint compared to mean values of $\mathrm{FCH}_{4 \mathrm{EC}}$ during the same time. The bars represent the maximum and minimum FC measurement during one deployment. The colours in the figure show the mean wind speed during the FC deployment period. Red circles enclosing filled circles represent the four comparisons of EC2 and FC. Black circles enclosing filled circles mark FCs with deployment times longer than $30 \mathrm{~min}$ in the EC1 footprint. The black line shows a $1: 1$ relation. The total number of direct comparisons $n=51$.

from wetlands and peatlands (e.g. Baldocchi et al., 2012; Roulet et al., 1992). In 2011 (Fig. 2a and b), $\mathrm{FCH}_{4 \mathrm{EC} 1}$ frequently displayed a diurnal cycle with higher values during night-time than during day. The diurnal cycle of $\mathrm{FCH}_{4}$ is presented in detail by Podgrajsek et al. (2014) where it was suggested that the onset of a diurnal cycle of $\mathrm{FCH}_{4}$ was controlled by water-side convection and formation of methane in the sediment. Such a pattern with convective driven high night-time fluxes was previously observed using flux chambers (Crill et al., 1988; Godwin et al., 2013), while studies from other lakes have found higher daytime $\mathrm{CH}_{4}$ emissions (e.g. Bastviken et al., 2004, 2010; Keller and Stallard, 1994). In summer 2012 (Fig. 2c), $\mathrm{FCH}_{4}$ was also measured from an additional EC tower positioned at the shore, $\mathrm{FCH}_{4 \mathrm{EC} 2}$. As expected, because of the position of the tower, the mean value of $\mathrm{FCH}_{4 \mathrm{EC} 2}$ from 13 June 12 to 15 June $12\left(\right.$ mean $\left.=1.77 \mathrm{mmol} \mathrm{m}^{-2} \mathrm{~d}^{-1}\right)$ was higher than both $\mathrm{FCH}_{4 \mathrm{EC} 1}\left(\right.$ mean $\left.=0.88 \mathrm{mmol} \mathrm{m}^{-2} \mathrm{~d}^{-1}\right)$ and $\mathrm{FCH}_{4 \mathrm{FC}}$ (mean $\left.=0.89 \mathrm{mmol} \mathrm{m}^{-2} \mathrm{~d}^{-1}\right)$ for the same period.

We conducted a total of 51 individual direct comparisons of FC and EC estimates of methane flux (Fig. 3). A linear best fit to the data points gives a correlation coefficient, $r$, of only 0.3 , indicating a limited correspondence between $\mathrm{FCH}_{4 \mathrm{EC}}$ and $\mathrm{FCH}_{4 \mathrm{FC}}$. Still, the mean relative error between the FC and EC measurements is only 0.2. The outcome of the comparison appears robust towards FC deployment time, as indicated by the similar patterns for FCs deployed with $30 \mathrm{~min}$ or longer deployment times (Fig. 3). Wind speed is impor- 


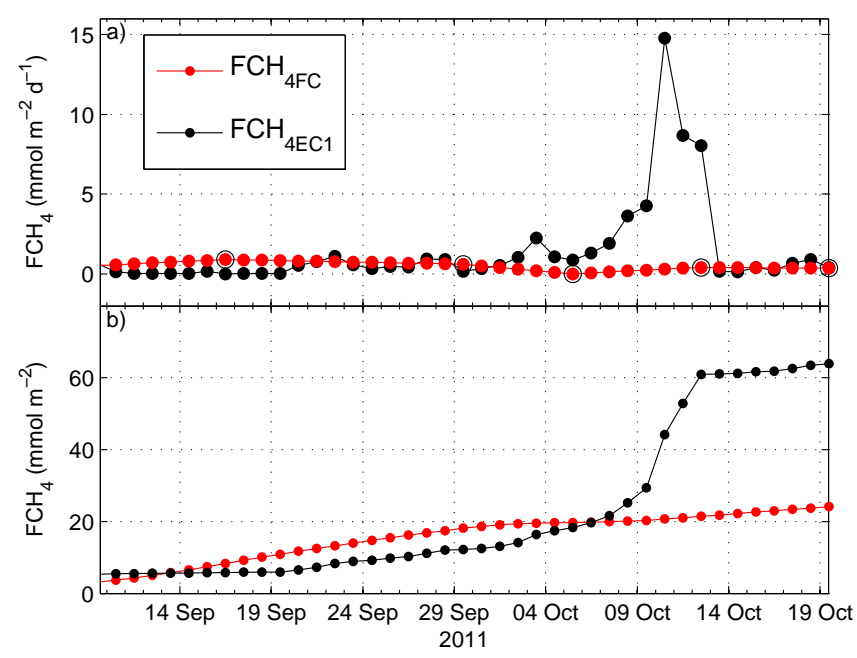

Figure 4. (a) Mean daily $\mathrm{FCH}_{4 \mathrm{EC} 1}$, (black dots) and $\mathrm{FCH}_{4 \mathrm{FC}}$ (red dots), calculated from half hour mean values of half hour fluxes showed in Fig. 2b. Gaps in the measurements have been filled by linear interpolation between the nearest neighbour. The encircled red dots indicate the $\mathrm{FCH}_{4 \mathrm{FC}}$ measurement occasions. (a) Cumulative sum of the daily $\mathrm{FCH}_{4 \mathrm{EC} 1}$, (black dots) and $\mathrm{FCH}_{4 \mathrm{FC}}$, (red dots). Note that $\mathrm{FCH}_{4 \mathrm{FC}}$ estimates were not continuous but based on a limited number of $30 \mathrm{~min}$ daytime measurements which seems to have coincided with relatively low flux estimates from EC1. Continuous $24 \mathrm{~h}$ flux chamber measurements covering also the periods with high EC fluxes might therefore have resulted in better agreement than indicated by (b).

tant for the efficiency of gas flux (e.g. Wanninkhof, 1992), and the FC and EC method may perform differently at different wind speeds. However, there is no indication that wind speed affects the agreement between the two methods. Comparisons at both low and high wind speeds yield similar results. Overall, magnitudes of the two method measurements are of the same order especially when taking into account the maximum and minimum chamber values.

The mean flux of both $\mathrm{FCH}_{4 \mathrm{FC}}$ and $\mathrm{FCH}_{4 \mathrm{EC}}$ measured simultaneously $\left(\approx 0.9 \mathrm{mmol} \mathrm{m}^{-2} \mathrm{~d}^{-1}\right)$ are of the same order as previously measured $\mathrm{FCH}_{4}$ in lakes at similar latitudes as lake Tämnaren (Bastviken, 2009). However, as mentioned before, in 2011 the EC method frequently measured nighttime fluxes substantially higher than this mean value and it is unclear how the methods would compare if these high flux events were considered.

Short-term daytime flux chamber data are often extrapolated in time, and there is a concern of biased flux estimates (Bastviken et al., 2004). A comparison between the cumulative extrapolated FC fluxes and the cumulative EC1 fluxes for $\mathrm{FCH}_{4}$ during the fall 2011 illustrates this risk (Fig. 4). For the FC measurements, which where only made biweekly during this period, daily mean values during days with measurements were used to interpolate $\mathrm{FCH}_{4 \mathrm{FC}}$ until the next measuring occasion. The cumulative sum of the EC method sums
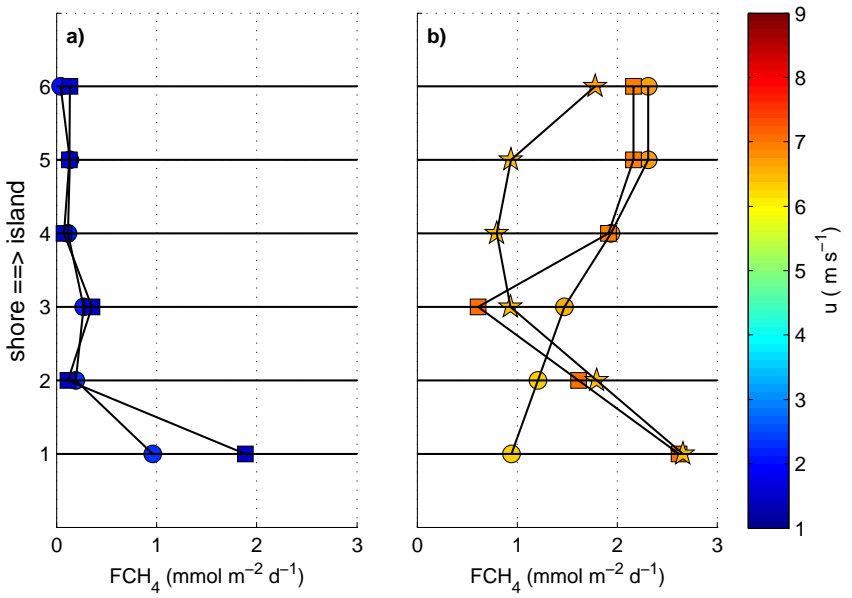

Figure 5. $\mathrm{FCH}_{4 \mathrm{FC}}$ measurements conducted along a transect from the shore to the island of Rättarharet marked with numbers 1-6 in Fig. 1 for (a) 12 June 2012 19:30 to 13 June 2012 4:00 and (b) 14 June 2012 11:00 to 14 June 2012 19:00. The colours represent the wind speed and the different symbols mark chambers measured during the same time.

to over $60 \mathrm{mmol} \mathrm{m}^{-2}$ during one and a half months and $\mathrm{FC}$ to only $24 \mathrm{mmol} \mathrm{m}^{-2}$ (Fig. 4b). Although the potential problem with discontinuous flux measurements are widely recognized, they are rarely compared to continuous measurements for lakes. Our analysis highlights the need for continuous or high frequency flux measurements, e.g. by EC measurements or by other approaches such as automated FC measurements (e.g. Duc et al., 2013).

\subsection{Spatial variations of $\mathrm{FCH}_{4}$}

To investigate the spatial variability of $\mathrm{CH}_{4}$ flux in lake Tämnaren, fluxes were measured with FCs at six locations along a transect from the shoreline to Rättarharet (Fig. 1). The measurements are divided into two periods; 12 June 2012 19:30 (all times are expressed in LT) to 13 June 2012 4:00 and 14 June 2012 11:00 to 14 June 2012 19:00 (Fig. 5a and b, respectively). During the first period, the magnitudes of the fluxes are small at all positions except close to the shore, position 1 (Fig. 5a), a region previously shown to be a strong emitter of methane (Bastviken et al., 2004). During the second period, when the wind speed is relatively high compared to the first period, the fluxes are in general higher than period 1 , as expected due to more efficient gas transfer (Fig. 5b). However, the spatial gradients are more variable during the second period, with one out of three horizontal gradients having the lowest flux close to the shore (circles Fig. 5b). This spatial variability of $\mathrm{FCH}_{4}$ that is measured with the FCs in the lake could not be captured with the EC method which measures the flux over a large area. This highlights one important difference between the FC and EC methods. 


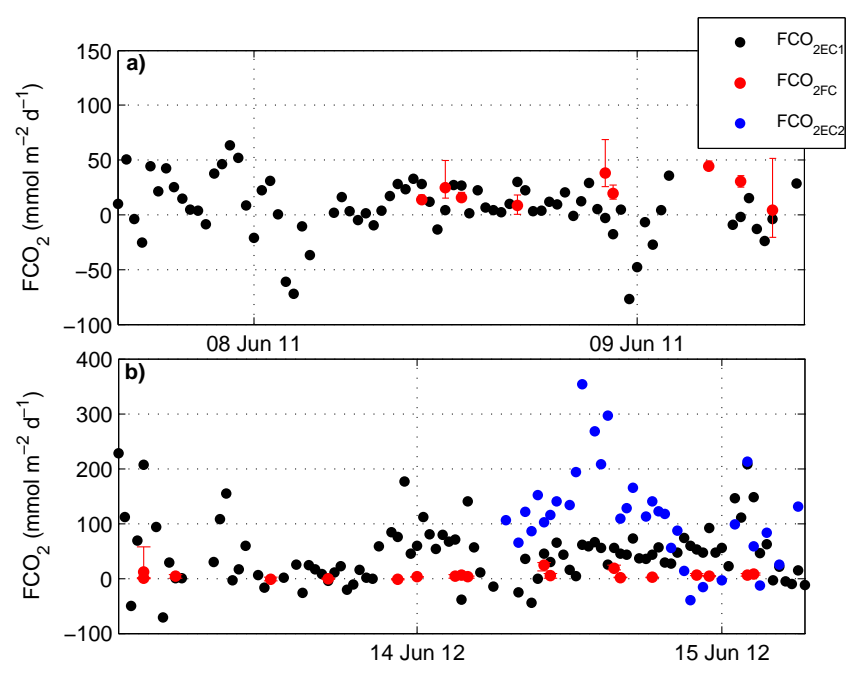

Figure 6. As Fig. 2 but for $\mathrm{CO}_{2}$ fluxes.

\subsection{Carbon dioxide flux comparison}

The time series of $\mathrm{CO}_{2}$ flux $\left(\mathrm{FCO}_{2}\right)$ measured with the $\mathrm{EC}$ method $\left(\mathrm{FCO}_{2 \mathrm{EC}}\right)$ and the $\mathrm{FC}$ method $\left(\mathrm{FCO}_{2 \mathrm{FC}}\right)$ during the two field campaigns are shown in Fig. 6. The mean values of $\mathrm{FCO}_{2 \mathrm{EC1}}$ differ significantly between the two years, with mean values of 8.2 and $47.2 \mathrm{mmol} \mathrm{m}^{-2} \mathrm{~d}^{-1}$, respectively. From fall 2011 to spring 2012 a higher amount of precipitation was observed compared to the same period in 2010/2011. The rainwater could have affected $p \mathrm{CO}_{2 \mathrm{w}}$ in the lake directly by transporting inorganic carbon via runoff or indirectly by transport of DOC (dissolved organic carbon). In-lake mineralization of DOC is shown to affect $p \mathrm{CO}_{2 \mathrm{w}}$ (Sobek et al., 2005). A higher amount of $p \mathrm{CO}_{2 \mathrm{w}}$ in 2012 compared to 2011 could thus lead to higher $\mathrm{FCO}_{2}$. Other factors such as sun light and temperature could also increase $p \mathrm{CO}_{2 \mathrm{w}}$ due to increased respiration. However, measurements show that air temperature and incoming solar radiation were higher in 2011 than 2012. Because $p \mathrm{CO}_{2 \mathrm{w}}$ was not measured in 2011, these discussions are only speculations.

The magnitude of $\mathrm{FCO}_{2 \mathrm{EC}}$ (from both $\mathrm{EC1}$ and EC2) ranges from negative values in 2011 to as high as $300 \mathrm{mmol} \mathrm{m}^{-2} \mathrm{~d}^{-1}$ in 2012 . This is comparable to what previous studies using the EC method have measured above lakes: e.g. Anderson et al. (2010) measured fluxes up to $230 \mathrm{mmol} \mathrm{m}^{-2} \mathrm{~d}^{-1}$, while Huotari et al. (2011) measured negative $\mathrm{FCO}_{2}$ explained by extremely high primary production.

Direct comparisons of the two methods during the 2012 campaign (28, in total) disagreed substantially, by $\approx 200 \mathrm{mmol} \mathrm{m}^{-2} \mathrm{~d}^{-1}$ (Fig. 7). The highest disagreements are mostly from night-time cases. There is no indication that wind speed influences the comparison. The poor agreement between the estimates of $\mathrm{FCO}_{2}$ is analysed further in the next section.

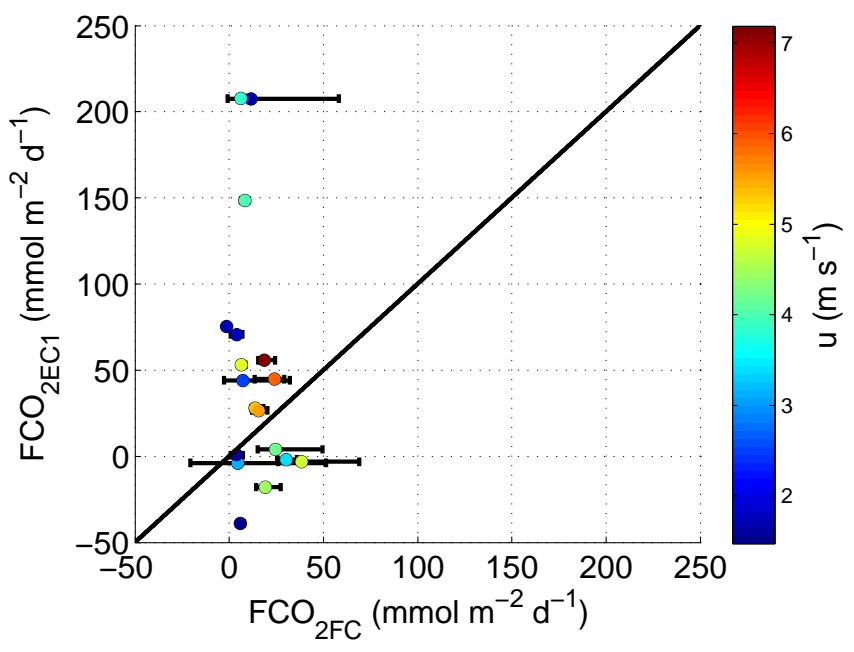

Figure 7. As Fig. 3 but for $\mathrm{CO}_{2}$ fluxes. Number of direct comparisons $n=18$.

\subsection{Further Analysis of $\mathrm{FCO}_{2}$ during the 2012 Campaign}

The EC and FC fluxes from the field campaign in 2012 are compared to a bulk flux estimation, Eq. (1) (Fig. 8). The $p \mathrm{CO}_{2 \mathrm{w}}$ value from the SAMI was used in the bulk flux estimation and the transfer velocity was parameterized using the wind speed dependent relation by Cole and Caraco (1998); $k_{\mathrm{u}}=2.07+0.215 \times u_{\mathrm{u}}^{1.7}$. Because $p \mathrm{CO}_{2 \mathrm{w}}$ may be inhomogeneous in the lake both horizontally and vertically, the bulk flux was also calculated with $p \mathrm{CO}_{2 \mathrm{wSAMI}}+200 \mathrm{ppm}$ and $p \mathrm{CO}_{2 \mathrm{wSAMI}}$ to $200 \mathrm{ppm}$. The bulk flux estimation shows a peak on midday 14 June with magnitudes comparable to $\mathrm{FCO}_{2 \mathrm{EC} 1}$ (Fig. 8). During the night between 13 and 14 June when disagreement between the EC and FC method are largest, the estimated bulk flux is more comparable to $\mathrm{FCO}_{2 \mathrm{FC}}$.

Many authors have stressed that convection in lakes and oceans will enhance the gas flux and that parameterizations of $k$ should include a dependence on convection (e.g. Eugster et al., 2003; MacIntyre et al., 2001; Rutgersson and Smedman, 2010; Rutgersson et al., 2011). Convection in the water can be estimated with the waterside buoyancy flux, $B\left(\mathrm{~m}^{2} \mathrm{~s}^{-3}\right)$, defined as

$B=\frac{g a Q_{\mathrm{eff}}}{c_{\mathrm{pw}} \rho_{\mathrm{w}}}$,

where $g$ is the acceleration of gravity $\left(\mathrm{m} \mathrm{s}^{-2}\right), a$ is the thermal expansion coefficient $\left(\mathrm{K}^{-1}\right), Q_{\text {eff }}$ is the effective surface heat flux defined as the sum of the total heat flux, longwave radiation and short-wave radiation $\left(\mathrm{J} \mathrm{s}^{-1} \mathrm{~m}^{-2}\right), c_{\mathrm{pw}}$ is the specific heat of water $\left(\mathrm{J} \mathrm{kg}^{-1} \mathrm{~K}^{-1}\right)$ and $\rho_{\mathrm{w}}$ is the density of the water $\left(\mathrm{kg} \mathrm{m}^{-3}\right)$ (Imberger, 1985; Jeffery et al., 2007). Rutgersson and Smedman (2010) suggested that $k$ parameterization can be separated into a wind speed dependent 


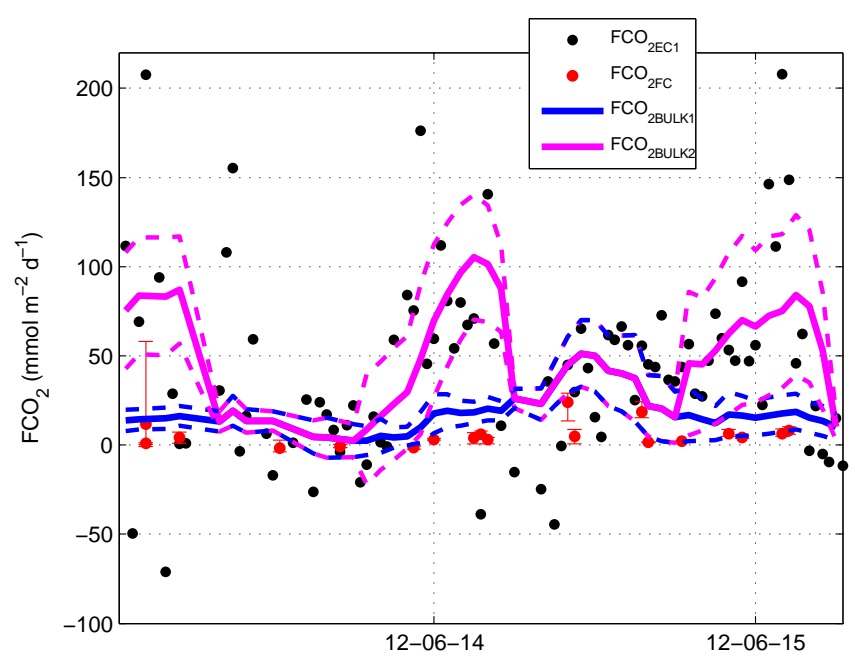

Figure 8. Time series from the field campaign in 2012, of $\mathrm{FCO}_{2 \mathrm{EC} 1}$, (black dots), $\mathrm{FCO}_{2 \mathrm{FC}}$, (red dots), $\mathrm{FCO}_{2 \mathrm{BULK} 1}, \mathrm{CO}_{2}$ flux calculated using the bulk flux estimation of Cole and Caraco (1998) (solid blue line) and $\mathrm{FCO}_{2} \mathrm{BULK}_{2}, \mathrm{CO}_{2}$ flux estimations using the bulk flux equation with $k$ dependent on both wind speed and waterside convection, i.e. Rutgersson and Smedman (2010) parameterization (magenta line). The upper and lower dashed blue and magenta lines represent the bulk flux estimations using $p \mathrm{CO}_{2 \mathrm{wSAMI}}+$ $200 \mathrm{ppm}$ and $p \mathrm{CO}_{2 \mathrm{wSAMI}}-200 \mathrm{ppm}$, respectively.

part, $k_{\mathrm{u}}$, and a part dependent on the waterside convection, $k_{\mathrm{c}}$, where $k_{\mathrm{c}}$ is a function of $w^{*}\left(\mathrm{~m} \mathrm{~s}^{-1}\right)$. The waterside convective velocity scale, is defined as

$w^{*}=\left(B z_{\mathrm{ml}}\right)^{1 / 3}$

where the mixed layer depth, $z_{\mathrm{ml}}$, is set to $2 \mathrm{~m}$ assuming that the lake is well mixed. Using the linear relation between $k_{\mathrm{c}}$ and $w^{*}$ from Rutgersson and Smedman (2010) we investigate how the convection could affect the bulk flux estimation. The results show that the new bulk flux has better agreement with $\mathrm{FCO}_{2 \mathrm{EC} 1}$ during night-time (Fig. 8), indicating that convective mixing may be the process enhancing the night-time $\mathrm{CO}_{2}$ flux, captured with the EC method. However, this also suggests that the flux measured with the chambers, which compared better with the bulk flux estimation only dependent on wind speed, does not properly account for water-side convection. We may speculate that this is due to microphysical conditions, that when the chamber shelters the water surface it prevents radiant cooling of the surface and thus inhibiting microscale convection that would disturb the diffusive sublayer and enhance the flux. However, previous studies have seen that chambers can capture convection (Crill et al., 1988; Gålfalk et al., 2013) and thus it is not clear why the chambers should miss this process in Tämnaren.

\section{Summary and conclusions}

Two direct methods for gas flux measurements, eddy covariance and floating chamber methods, were compared for lake fluxes of $\mathrm{CO}_{2}$ and $\mathrm{CH}_{4}$ in Tämnaren.

For $\mathrm{FCH}_{4}$ our results show some different but similar flux magnitudes with the two methods (Fig. 3). However, when comparing cumulative $\mathrm{FCH}_{4 \mathrm{EC}}$ and $\mathrm{FCH}_{4 \mathrm{FC}}$ for a longer period it is clear that episodic high flux events can easily be missed when using a method that does not measure continuously. The results presented in Fig. 5 show that $\mathrm{FCH}_{4}$ varies horizontally in the lake and that this variation varies in time. This suggest that a direct comparison of $\mathrm{FCH}_{4}$ measured with the EC and FC method, which measure fluxes representing different surface areas, will not yield the same results.

$\mathrm{FCO}_{2}$ measured during the field campaign in 2011 showed similar flux magnitudes with both methods. However, for the field campaign in 2012 the comparison was poor (Figs. 6 and 7). The reason for this is not clear at present. While we here have identified a potential issue, we may currently only speculate about the reasons. We therefore highlight the importance of further comparisons between lake EC systems and flux chambers on lakes, specifically under conditions when water convection is a major driving force for fluxes. It is also important that future method comparisons are performed under homogeneous conditions where the influence of single factors can be isolated.

Overall, we show that although FC and EC methods yielded flux estimates in the same order of magnitude there are important differences that have to be considered. Clearly, short term, discontinuous FC measurements are likely to be biased by missing episodic flux events and possible very important diurnal variability. Further, EC and FC methods cover different areas making EC advantageous for integrated measurements over larger areas, while the FC approach is suitable for local and spatially well constrained flux measurements. Hence, EC and FC methods should be seen as supplementary rather than fully comparable methods.

Acknowledgements. This study was sponsored by the Swedish research council FORMAS as a part of the project Color of Water (CoW). J. Holst and A. Lindroth were supported by the VR funded Linnaues Centre LUCCI at Lund University. We would like to thank all people involved in the field campaigns and especially Roger Müller for all the help with the chamber measurements.

Edited by: X. Wang

\section{References}

Anderson, D. E., Striegl, R. G., Stannard, D. I., Catherine, M., Mcconnaughey, T. A., and Labaugh, J. W.: Estimating lakeatmosphere $\mathrm{CO}_{2}$ exchange, Am. Soc. Limnol. Oceanogr., 44, 988-1001, 2010. 
Baldocchi, D. D.: Assessing the eddy covariance technique for evaluating carbon dioxide exchange rates of ecosystems?: past, present and future, Glob. Chang. Biol., 9, 479-492, 2003.

Baldocchi, D., Detto, M., Sonnentag, O., Verfaillie, J., Teh, Y. A., Silver, W., and Kelly, N. M.: The challenges of measuring methane fluxes and concentrations over a peatland pasture, Agric. For. Meteorol., 153, 177-187, 2012.

Bastviken, D.: Methane, in: Encycloped, edited by: Likens, G., Oxford Elsevier, 783-805, 2009.

Bastviken, D., Cole, J., Pace, M., and Tranvik, L.: Methane emissions from lakes: Dependence of lake characteristics, two regional assessments, and a global estimate, Global Biogeochem. Cy., 18, GB4009, doi:10.1029/2004GB002238, 2004.

Bastviken, D., Santoro, A. L., Humberto, M., Debora Fernandes, C., Crill, P., and Enrich-prast, A.: Methane emissions from Pantanal, South America, during the low water season: toward more comprehensive sampling., Environ. Sci. Technol., 44, 5450-5, 2010.

Bastviken, D., Tranvik, L., and Downing, J.: Freshwater methane emissions offset the continental carbon sink, Science, 331, 5050, 2011.

Cole, J. J. and Caraco, N. F.: Atmospheric exchange of carbon dioxide in a low-wind oligotrophic lake measured by the addition of SF6, Limnol. Oceanogr., 43, 647-656, 1998.

Cole, J. J., Prairie, Y. T., Caraco, N. F., McDowell, W. H., Tranvik, L. J., Striegl, R. G., Duarte, C. M., Kortelainen, P., Downing, J. a., Middelburg, J. J., and Melack, J.: Plumbing the global carbon cycle: Integrating inland waters into the terrestrial carbon budget, Ecosystems, 10, 172-185, 2007.

Cole, J. J., Bade, D. L., Bastviken, D., Pace, M. L., and Bogert, M. Van De: Multiple approaches to estimating air-water gas exchange in small lakes, Limnol. Oceanogr. Methods, 8, 285-293, 2010.

Crill, P., Bartlett, K. B., Wilson, J. O., Sebacher, D. I., Harriss, R. C., Melack, J. M., Macintyre, S., Lesack, L., and Lesley, S.-M.: Tropospheric methane from an Amazonian floodplain lake, J. Geophys. Res., 93, 1564-1570, 1988.

Downing, J. a., Prairie, Y. T., Cole, J. J., Duarte, C. M., Tranvik, L. J., Striegl, R. G., McDowell, W. H., Kortelainen, P., Caraco, N. F., and Melack, J. M.: The global abundance and size distribution of lakes, ponds, and impoundments, Limnol. Oceanogr., 51, 23882397, 2006.

Duc, N. T., Silverstein, S., Lundmark, L., Reyier, H., Crill, P., and Bastviken, D.: Automated flux chamber for investigating gas flux at water-air interfaces, Environ. Sci. Technol., 47, 968-75, 2013.

Eugster, W., Kling, G. W., Jonas, T., McFadden, J. P., Wuest, A., MacIntyre, S., and Chapin III, S. F.: $\mathrm{CO}_{2}$ exchange between air and water in an Arctic Alaskan and midlatitude Swiss lake: Importance of convective mixing, J. Geophys. Res., 108, 4362, doi:10.1029/2002JD002653, 2003.

Eugster, W., DelSontro, T., and Sobek, S.: Eddy covariance flux measurements confirm extreme $\mathrm{CH}_{4}$ emissions from a Swiss hydropower reservoir and resolve their short-term variability, Biogeosciences, 8, 2815-2831, doi:10.5194/bg-8-2815-2011, 2011.

Forster, P., Ramaswamy, V., Artaxo, P., Berntsen, T., Betts, R., Fahey, D. W., Haywood, J., Lean, J., Lowe, D. C., Myhre, G., Nganga, J., Prinn, R., Raga, G., Schulz, M., and Dorland, R.: Changes in atmospheric constituents and in radiative forcing, Clim. Chang. 2007 Phys. Sci. Basis. Contrib. Work Gr. I to Fourth Assess. Rep. Intergov. Panel Clim. Chang. Cambridge
Univ. Press Cambridge, United Kingdom New York, NY, USA, 2007.

Godwin, C. M., McNamara, P. J., and Markfort, C. D.: Evening methane emission pulses from a boreal wetland correspond to convective mixing in hollows, J. Geophys. Res. Biogeosci., 118, 994-1005, doi:10.1002/jgrg.20082, 2013.

Gålfalk, M., Bastviken, D., Fredriksson, S., and Arneborg, L.: Determination of the piston velocity for water-air interfaces using flux chambers, acoustic Doppler velocimetry, and IR imaging of the water surface, J. Geophys. Res. Biogeosciences, 118, 770782, 2013, http://www.biogeosciences.net/118/770/2013/.

Huotari, J., Ojala, A., Peltomaa, E., Nordbo, A., Launiainen, S., Pumpanen, J., Rasilo, T., Hari, P., and Vesala, T.: Long-term direct CO 2 flux measurements over a boreal lake: Five years of eddy covariance data, Geophys. Res. Lett., 38, L18401, doi:10.1029/2011GL048753, 2011.

Huttunen, J. T., Alm, J., Liikanen, A., Juutinen, S., Larmola, T., Hammar, T., Silvola, J., and Martikainen, P. J.: Fluxes of methane, carbon dioxide and nitrous oxide in boreal lakes and potential anthropogenic effects on the aquatic greenhouse gas emissions, Chemosphere, 52, 609-21, 2003.

Imberger, J.: The diurnal mixed layer, Limnol. Oceanogr., 30, 737$770,1985$.

Jeffery, C. D., Woolf, D. K., Robinson, I. S., and Donlon, C. J.: One-dimensional modelling of convective $\mathrm{CO}_{2}$ exchange in the Tropical Atlantic, Ocean Model., 19, 161-182, 2007.

Jonsson, A., Åberg, J., Lindroth, A., and Jansson, M.: Gas transfer rate and $\mathrm{CO}_{2}$ flux between an unproductive lake and the atmosphere in northern Sweden, J. Geophys. Res., 113, G04006, doi:10.1029/2008JG000688, 2008.

Keller, M. and Stallard, F.: Methane emission by bubbling from Gatun Lake, Panama, J. Geophys. Res., 99, 8307-8319, 1994.

MacIntyre, S., Eugster, W., and Kling, G. W.: The critical importance of buoyancy flux for gas flux across the air-water interface, in: Gas Transfer at Water Surfaces, edited by: Donelan, M. A. et al., 135-139, 2001.

McDermitt, D., Burba, G., Xu, L., Anderson, T., Komissarov, a., Riensche, B., Schedlbauer, J., Starr, G., Zona, D., Oechel, W., Oberbauer, S., and Hastings, S.: A new low-power, open-path instrument for measuring methane flux by eddy covariance, Appl. Phys. B, 102, 391-405, 2010.

Podgrajsek, E., Sahlée, E., and Rutgersson, A.: Diurnal cycle of lake methane flux, J. Geophys. Res. Biogeosciences, 119, 236-248, 2014 , http://www.biogeosciences.net/119/236/2014/.

Riera, J. L., Schindler, J. E., Kratz, T. K., and Lake, C.: Seasonal dynamics of carbon dioxide and methane in two clear-water lakes and two bog lakes in northern Wisconsin, USA, Can. J. Fish. Aquat. Sci., 274, 265-274, 1999.

Roulet, N., Moore, T., Bubier, J., and Lafleur, P.: Noerthern fens methane flux and climatic change, Tellus, 44B, 100-105, 1992.

Rutgersson, A. and Smedman, A.: Enhanced air-sea $\mathrm{CO}_{2}$ transfer due to water-side convection, J. Mar. Syst., 80, 125-134, 2010.

Rutgersson, A., Smedman, A., and Sahlée, E.: Oceanic convective mixing and the impact on air-sea gas transfer velocity, Geophys. Res. Lett., 38, L02602, doi:10.1029/2010GL045581, 2011. 
Sahlée, E., Rutgersson, A., Podgrajsek, E., and Bergström, H.: Influence from surrounding land on the turbulence measurements above a lake, Boundary-Layer Meteorol., 150, 235-258, 2014.

Sahlée, E., Smedman, A.-S., Rutgersson, A., and Högström, U.: Spectra of $\mathrm{CO} 2$ and water vapour in the marine stmospheric durface layer, Boundary-Layer Meteorol., 126, 279-295, 2007.

Schubert, C. J., Diem, T., and Eugster, W.: Methane emissions from a small wind shielded lake determined by eddy covariance, flux chambers, anchored funnels, and boundary model calculations: a comparison, Environ. Sci. Technol., 46, 4515-22, 2012.

Sobek, S., Tranvik, L. J., and Cole, J. J.: Temperature independence of carbon dioxide supersaturation in global lakes, Global Biogeochem. Cy., 19, GB2003, doi:10.1029/2004GB002264, 2005.

Wang, J. M., Murphy, J. G., Geddes, J. a., Winsborough, C. L., Basiliko, N., and Thomas, S. C.: Methane fluxes measured by eddy covariance and static chamber techniques at a temperate forest in central Ontario, Canada, Biogeosciences, 10, 4371-4382, doi:10.5194/bg-10-4371-2013, 2013.

Wang, M., Guan, D.-X., Han, S.-J., and Wu, J.-L.: Comparison of eddy covariance and chamber-based methods for measuring $\mathrm{CO}_{2}$ flux in a temperate mixed forest., Tree Physiol., 30, 14963, 2010.
Wanninkhof, R.: Relationship between wind speed and gas exchange over the ocean, J. Geophys. Res., 97, 7373-7382, 1992.

Webb, E. K., Pearman, G. I., and Leuning, R.: Correction of flux measurements for density effects due to heat and water vapour transfer, Quart. J. Roy. Meteorol. Soc., 106, 85-100, 1980.

Vesala, T., Huotari, J., Rannik, Ü., Suni, T., Smolander, S., Sogachev, A., Launiainen, S., and Ojala, A.: Eddy covariance measurements of carbon exchange and latent and sensible heat fluxes over a boreal lake for a full open-water period, J. Geophys. Res., 111, D11101, doi:10.1029/2005JD006365, 2006.

Woolf, D. K.: Bubbles and the air-sea transfer velocity of gases, Atmosphere-Ocean, 31, 517-540, 1993.

Zappa, C. J., Asher, W. E., and Jessup, A. T.: Microscale wave breaking and air-water gas transfer, J. Geophys. Res., 106, 93859391, 2001. 